\title{
A New Diphenyl Ether from Marine-derived Fungus Aspergillus sp. B-F-2
}

\author{
Rui Liu, Weiming Zhu, Yapeng Zhang, Tianjiao Zhu, Hongbing Liu, Yuchun Fang, \\ Qianqun Gu
}

Received: March 16, 2006 / Accepted: May 30, 2006

(C) Japan Antibiotics Research Association

\begin{abstract}
A new diphenyl ether dimethyl 2,3'dimethylosoate (1) together with three known compounds monomethylsulochrin (2), emodin (3), and questin (4) were isolated through bioassay-guided fractionations from the culture of a marine-derived fungus Aspergillus sp. B-F-2. The structures of these compounds were determined by spectroscopic methods. Cytotoxicities of compounds $\mathbf{1}$ and 2 against K562 cell line were preliminarily evaluated by the MTT method and flow cytometry.
\end{abstract}

Keywords Aspergillus sp., diphenyl ether, asterric acid, anthraquinone, cytotoxicity

\section{Introduction}

In our research for new anticancer microbial metabolites, a culture broth of a marine-derived fungus Aspergillus sp. B-F-2, exerted significant cytotoxic activity against K562 cell line. Bioassay-guided isolation led to one new asterric acid derivative dimethyl 2,3'-dimethoxyosoate (1), and three known fungal metabolites monomethylsulochrin (2), emodin (3), and questin (4) (Fig. 1).

Asterric acid, possessing a diphenyl ether structure, was the first non-peptide endothelin (ET) binding inhibitor discovered $[1,2]$. In this paper we mainly report the isolation and structure determination of the new diphenyl ether (1), and its preliminary in vitro cytotoxicity against the

W. Zhu, Q. Gu (Corresponding authors), R. Liu, Y. Zhang, T. Zhu, H. Liu, Y. Fang: Key Laboratory of Marine Drugs, Chinese Ministry of Education; Institute of Marine Drugs and Food, Ocean University of China, Qingdao 266003, PR China, E-mail: weimingzhu@ouc.edu.cn,quqiang@ouc.edu.cn
K562 cell line. These kinds of compounds are formed biosynthetically from the anthraquinone emodin, via sulochrin, and grisandienes such as geodin was previously reported $[3,4]$.

\section{Materials and Methods}

\section{Fungal Material}

The fungus Aspergillus sp. B-F-2 was isolated from the marine sediments collected in Behai Bay, China. It was preserved in the China Center for Type Culture Collection (patent depositary number: B-F-2 CCTCC M 205148). Working stocks were prepared on Potato Dextrose agar slants stored at $4^{\circ} \mathrm{C}$.

\section{Fermentation and Extraction}

The fungus was grown under static conditions at $24^{\circ} \mathrm{C}$ for 25 days in $1000 \mathrm{ml} \times 150$ conical flasks containing the liquid medium ( $300 \mathrm{ml} /$ flask) composed of glucose $(20 \mathrm{~g} /$ liter $)$, peptone $(5.0 \mathrm{~g} /$ liter $)$, malt extract $(3.0 \mathrm{~g} /$ liter $)$ and yeast extract $(3.0 \mathrm{~g} /$ liter $)$ and sea-water after adjusting its $\mathrm{pH}$ to 7.0 . The fermented whole broth (45 liter) was
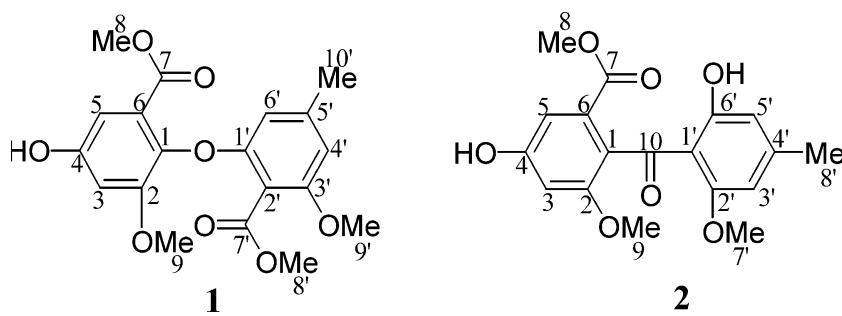

Fig. 1 Structures of compounds $\mathbf{1}$ and $\mathbf{2}$. 
filtered through cheese cloth to separate the supernatant from the mycelia. The former was concentrated under reduced pressure to about a quarter of the original volume and then extracted three times with ethyl acetate to give an ethyl acetate solution, while the latter was extracted three times with acetone. The acetone solution was concentrated under reduced pressure to afford an aqueous solution. The aqueous solution was extracted three times with ethyl acetate to give another ethyl acetate solution. Both ethyl acetate solutions were combined and concentrated under reduced pressure to give a crude extract $(22.0 \mathrm{~g})$.

\section{Purification}

The crude extract $(22.0 \mathrm{~g})$ showed strong cytotoxity against $\mathrm{K} 562$ cells at $50 \mu \mathrm{g} / \mathrm{ml}$. It was separated into 12 fractions on a silica gel column using a step gradient elution of $\mathrm{CHCl}_{3}: \mathrm{MeOH}$. The bioactive fraction 3, eluted with $\mathrm{CHCl}_{3}: \mathrm{MeOH} 98: 2(2.9 \mathrm{~g})$, was further separated on another silica gel column using a step gradient elution of petroleum ether: acetone to give compounds $3(100 \mathrm{mg})$ and $4(200 \mathrm{mg})$. The bioactive fraction 5 , eluted with $\mathrm{CHCl}_{3}: \mathrm{MeOH} 95: 5$ (1.6g), was subjected to a Sephadex LH20 column chromatography $(100 \% \mathrm{MeOH})$ and further purified by semiprepartive HPLC [YMC-Pack ODSA, $10 \times 250 \mathrm{~mm}, 5 \mu \mathrm{m}, 4 \mathrm{ml} /$ minute] eluted with $\mathrm{MeOH}: \mathrm{H}_{2} \mathrm{O}$ ( $60: 40,4.0 \mathrm{ml} / \mathrm{minute})$ to give compounds $\mathbf{1}(30 \mathrm{mg})$ and $\mathbf{2}$ (58 mg).

\section{Biological Assays}

The human chronic myelogenous leukemia cell line K562 was grown in RPMI 1640 culture medium supplemented with $10 \%$ fetal calf serum, $100 \mathrm{U} / \mathrm{ml}$ penicillin $\mathrm{G}$, and $100 \mu \mathrm{g} / \mathrm{ml}$ streptomycin at $37^{\circ} \mathrm{C}$ in $5 \% \quad \mathrm{CO}_{2} / 100 \%$ humidified air.

Cytotoxic activity was evaluated by the MTT method [5] using the K562 cell line. $200 \mu \mathrm{l}$ of the cell suspensions at a density of $5 \times 10^{3} \mathrm{cell} / \mathrm{ml}$ were plated in 96 well microtiter plates under the above conditions. Then $2 \mu \mathrm{l}$ of the test compound solutions (in DMSO) at different concentrations was added to each well and further incubated for 72 hours under the same conditions. $20 \mu \mathrm{l}$ of the MTT solution $(5 \mathrm{mg} / \mathrm{ml}$ in PBS) was added to each well and incubated for 4 hours. One hundred fifty $\mu \mathrm{l}$ of the spent medium containing MTT was then gently replaced by DMSO and pipetted to dissolve any formazan crystals formed. Absorbance was then determined on a SPECTRA MAX PLUS plate reader at $570 \mathrm{~nm}$.

For apoptosis assessment, cells were plated in 12-well cell culture plates $\left(5 \times 10^{4}\right.$ cells/well $)$ in triplicate and treated with DMSO (control) or compounds (1 and 2) at the indicated concentrations (Table 2) for 72 hours. Cells were
Table $1600 \mathrm{MHz}{ }^{1} \mathrm{H}$ and $150 \mathrm{MHz}{ }^{13} \mathrm{C}$ NMR data of compound $\mathbf{1}$ in $\mathrm{CDCl}_{3}$

\begin{tabular}{|c|c|c|}
\hline \multirow{2}{*}{ Position } & \multicolumn{2}{|c|}{1} \\
\hline & $\delta_{\mathrm{C}}$ & $\delta_{\mathrm{H}}(\mathrm{J}$ in $\mathrm{Hz})$ \\
\hline 1 & $136.2 \mathrm{~s}$ & - \\
\hline 2 & $154.2 \mathrm{~s}$ & - \\
\hline 3 & $105.1 d$ & $6.69(1 \mathrm{H}, \mathrm{d}, 2.9)$ \\
\hline 4 & $153.5 \mathrm{~s}$ & - \\
\hline 5 & $108.5 d$ & $7.00(1 \mathrm{H}, \mathrm{d}, 2.9)$ \\
\hline 6 & $125.9 \mathrm{~s}$ & - \\
\hline 7 & $166.3 \mathrm{~s}$ & - \\
\hline 8 & $52.5 q$ & $3.74(3 \mathrm{H}, \mathrm{s})$ \\
\hline 9 & $56.4 \mathrm{q}$ & $3.72(3 \mathrm{H}, \mathrm{s})$ \\
\hline $1^{\prime}$ & $156.5 \mathrm{~s}$ & - \\
\hline $2^{\prime}$ & $109.9 \mathrm{~s}$ & - \\
\hline $3^{\prime}$ & $157.3 \mathrm{~s}$ & - \\
\hline $4^{\prime}$ & $105.0 \mathrm{~d}$ & $6.36(1 \mathrm{H}, \mathrm{br} \mathrm{s})$ \\
\hline $5^{\prime}$ & $141.3 \mathrm{~s}$ & - \\
\hline $6^{\prime}$ & $106.4 d$ & $5.86(1 \mathrm{H}, \mathrm{br} \mathrm{s})$ \\
\hline $7^{\prime}$ & $167.0 \mathrm{~s}$ & - \\
\hline $8^{\prime}$ & $52.4 \mathrm{q}$ & $3.91(3 \mathrm{H}, \mathrm{s})$ \\
\hline $9^{\prime}$ & $55.9 q$ & $3.82(3 \mathrm{H}, \mathrm{s})$ \\
\hline $10^{\prime}$ & $22.1 \mathrm{q}$ & $2.19(3 \mathrm{H}, \mathrm{s})$ \\
\hline $4-\mathrm{OH}$ & & $5.97(1 \mathrm{H}, \mathrm{s})$ \\
\hline
\end{tabular}

harvested, washed twice with PBS and the cellular DNA was stained with $200 \mu \mathrm{l}$ of propidium iodide (PI, $50 \mu \mathrm{g} / \mathrm{ml}$, RNase $1 \mu \mathrm{g} / \mathrm{ml}$, Triton X-100 0.1\%). After incubation at $4^{\circ} \mathrm{C}$ for 20 minutes, cells were analyzed on a flow cytometer.

\section{Results and Discussion}

\section{Physico-chemical Properities}

Compound 1: white needles; mp $159 \sim 161^{\circ} \mathrm{C}$; HRESIMS $m / z$ : $375.1094[\mathrm{M}-\mathrm{H}]^{-}$; (calcd for $\mathrm{C}_{19} \mathrm{H}_{19} \mathrm{O}_{8}, 375.1080$ ); $\mathrm{UV} \lambda_{\max }\left(\mathrm{CHCl}_{3}\right) \mathrm{nm}(\log \varepsilon) 255$ (2.30), 308 (2.35); IR $v_{\max }(\mathrm{KBr}) \mathrm{cm}^{-1} 3377,2956,1707,1611,1588,1453$, 1314, 1281, 1099, 1061, 1008, 807; ${ }^{1} \mathrm{H}$ and ${ }^{13} \mathrm{C}$ NMR (see Table 1).

Compound 2: white needles; mp $199 \sim 200^{\circ} \mathrm{C}$; ESIMS $m / z: 369[\mathrm{M}+\mathrm{Na}]^{+} ; \mathrm{UV} \lambda_{\max }\left(\mathrm{CHCl}_{3}\right) \mathrm{nm}(\log \varepsilon) 260$ (2.09), 286 (2.27); IR $v_{\max }(\mathrm{KBr}) \mathrm{cm}^{-1} 3403,2992,1692$, 1606, 1447, 1354, 1215, 1062, 817, 638; ${ }^{13} \mathrm{C}$ NMR (acetone- $\left.d_{6}, 150 \mathrm{MHz}\right): \delta_{\mathrm{C}}=128.2(\mathrm{~s}, \mathrm{C}-1), 158.7(\mathrm{~s}, \mathrm{C}-2)$, 103.7 (d, C-3), 158.0 (s, C-4), 108.1 (d, C-5), 129.4 (s, C6), 166.7 (s, C-7), 52.2 (q, C-8), 56.4 (q, C-9), 200.4 (s, C- 


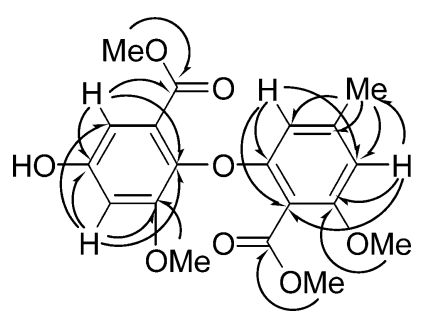

Fig. $2 \mathrm{HMBC}$ analysis of compound $\mathbf{1}$.

10), 111.4 (s, C-1'), 162.1 (s, C-2'), 103.9 (d, C-3'), 148.5 (s, C-4'), 111.1 (d, C-5'), 164.9 (s, C-6'), 56.2 (q, C-7'), $22.2\left(\mathrm{q}, \mathrm{C}-8^{\prime}\right) ;{ }^{1} \mathrm{H}$ NMR (acetone- $d_{6}, 600 \mathrm{MHz}$ ): $\delta_{\mathrm{H}}=6.74$ $(1 \mathrm{H}, \mathrm{d}, J=2.2, \mathrm{H}-3), 7.02(1 \mathrm{H}, \mathrm{d}, J=2.2, \mathrm{H}-5), 3.64(3 \mathrm{H}, \mathrm{s}$, $\mathrm{H}-8), 3.69$ (3H, s, H-9), $6.24(1 \mathrm{H}$, br s, H-3'), $6.37(1 \mathrm{H}$, br s, H-5'), 3.40 (3H, s, H-7'), 2.27 (3H, s, H- $\left.8^{\prime}\right)$.

\section{Structure Determination}

The bioactive ethyl acetate extract of the Aspergillus sp. was chromatographed on silica gel columns and reversed-phase preparative HPLC to give four pure compounds (1 $\sim \mathbf{4})$. Compounds $\mathbf{2} \sim \mathbf{4}$ were identified as monomethylsulochrin (2) [6,7], emodin (3), and questin (4) respectively, by comparison of their spectroscopic data with those reported in the literature.

The molecular formula of compound $\mathbf{1}$ was determined to be $\mathrm{C}_{19} \mathrm{H}_{20} \mathrm{O}_{8}$ from the negtive HRESIMS spectrum $\left(\mathrm{m} / \mathrm{z} 375.1094\right.$, cacld for $[\mathrm{M}-\mathrm{H}]^{-}$375.1080). The UV absorption maxima at 255 and $308 \mathrm{~nm}$ in $\mathrm{CHCl}_{3}$ resembled those of asterric acid derivatives, which possess the biphenyl ether structure [8]. In the IR spectrum, an absorption band at 1707 in combination with the broad band at $3377 \mathrm{~cm}^{-1}$ suggested the presence of an ester and a hydroxyl group, respectively. In the ${ }^{1} \mathrm{H}-\mathrm{NMR}$ spectrum, one methyl singlet at $\delta 2.19$, four methoxyl singlets at $\delta 3.72$, $3.74,3.82,3.91$, four benzen hydrogen signals at $\delta 5.86$, $6.36,6.69,7.00$, and one exchangable hydrogen proton signal at $\delta 5.97$ were observed. The ${ }^{13} \mathrm{C}$ NMR showed a total of 19 resonances. After the assignment of the carbons bearing hydrogens by the HMQC experiment, the structure of two aromatic ring moieties were determined by the HMBC experiments shown in Fig. 2. The two aromatic rings were bonded by an oxygen through an analysis of the carbon signals at $\mathrm{C}-1$ and $\mathrm{C}-1^{\prime}$, combined with the molecular formular. On the basis of the above data, the structure of 1 was determined.

\section{Cytotoxicities and Apoptosis}

The quantification of cellular growth, including viability, apoptosis and different phases of the cell cycle, has become an essential parameter in the evaluation of anticancer
Table 2 Distribution of the K562 cells within cell cycle and apoptosis ${ }^{\mathrm{a}}$

\begin{tabular}{ccrrrr}
\hline & & \multicolumn{4}{c}{ Distribution of the cells $(\%)$} \\
\cline { 3 - 6 } Compound & $\begin{array}{c}\text { Concentration } \\
(\mu \mathrm{M})\end{array}$ & Apo & $\mathrm{G}_{0} / \mathrm{G}_{1}$ & $\mathrm{~S}$ & $\mathrm{G}_{2} / \mathrm{M}$ \\
\hline \multirow{2}{*}{$\begin{array}{c}\text { Control } \\
\mathbf{1}\end{array}$} & - & 0.7 & 50.2 & 38.3 & 12.7 \\
& 100 & 11.5 & 29.0 & 56.4 & 4.6 \\
& 10 & 0.7 & 47.6 & 41.2 & 11.2 \\
& 1 & 0.8 & 54.2 & 33.2 & 12.6 \\
& 0.1 & 0.7 & 51.4 & 34.1 & 14.3 \\
$\mathbf{2}$ & 0.01 & 0.3 & 51.8 & 39.0 & 10.3 \\
& 100 & 0.5 & 49.8 & 37.3 & 12.9 \\
& 10 & 0.9 & 50.6 & 36.6 & 12.8 \\
& 1 & 0.5 & 52.7 & 37.0 & 10.3 \\
& 0.1 & 0.2 & 48.2 & 37.7 & 14.1 \\
& 0.01 & 0.8 & 51.0 & 34.7 & 14.1 \\
\hline
\end{tabular}

a Data were obtained from the histograms. Numbers in the column Apo represent relative percentage of the apoptotic cells counted in the sub$\mathrm{G}_{0} / \mathrm{G}_{1}$ peak region to the total cell numbers. The proportion of cells in each phase of the cell cycle $\left(G_{0} / G_{1}, S\right.$, and $\left.G_{2} / M\right)$ was analyzed with the computer software CellQuest.
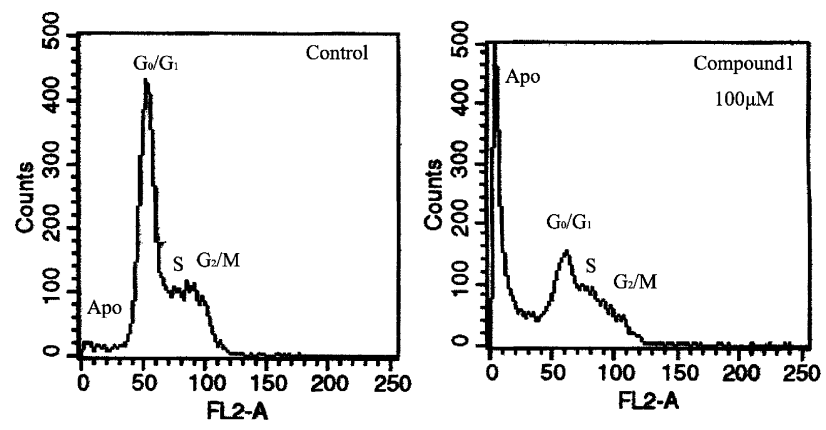

Fig. 3 Effects of $\mathbf{1}$ on K562 cell cycle and apoptosis.

The given result is a representative of three independent experiments.

activities of compounds. To evaluate the potential anticancer effect of compounds $\mathbf{1}$ and $\mathbf{2}$, cell viability and cellular DNA analyses were performed using K562 cells. A decrease in reduced MTT concentrations is generally observed in the presence of compound $1\left(\mathrm{IC}_{50}=76.5 \mu \mathrm{M}\right)$ whereas compound 2 has little effect $\left(\mathrm{IC}_{50}>100 \mu \mathrm{M}\right)$.

In the cell cycle and apoptosis assay, as shown in Table 2, 1 at $100 \mu \mathrm{M}$ increased the percentage of cells in the $\mathrm{S}$ phase of the cell cycle from $38.3 \%$ (Control) to $56.4 \%$. Meanwhile, after 72 hours treatment with $\mathbf{1}$ at the same concentration, the percentage of apoptotic cells was also increased (11.5\%) as compared with control group $(0.7 \%)$ (Fig. 3). In contrast, 2 at each concentration had 
little effect on cellular DNA, as compared with the control group. Collectively, we demonstrate for the first time that $\mathbf{1}$ inhibits cell viability through S-phase blockage of the cell cycle and cell apoptosis.

Compounds, possessing diphenyl ether skeleton, are common constituents of fungi metabolites, such as Pestalotiopsis sp. [8], Aspergillus sp. [2], and etc. Their reported bioactivities mainly focus on the endothelin (ET) binding inhibitory activities $[1,8]$, with nearly no reports on cytotoxicity. Our study demonstrated for the first time that compound having diphenyl ether skeleton showed $\mathrm{S}$ phase inhibitory activity against K562 cell line. Therefore it is important to further evaluate the cytotoxicity of diphenyl ether compounds for finding their structureactivity relationships.

Acknowledgement This work was financially supported by the Project of China Ocean Mineral Resources R\&D Association (No. DY-105-2-04-02).

\section{References}

1. Ohashi H, Akiyama H, Nishikori K, Mochizuki J. Asterric acid, a new endothelin binding inhibitor. J Antibiot 45:
1684-1685 (1992)

2. Hargreaves J, Park JO, Ghisalberti EL, Sivasithamparam K, Skelton BW, White AH. New chlorinated diphenyl ethers from an Aspergillus species. J Nat Prod 65: 7-10 (2002)

3. Chen ZG, Fujii I, Ebizuka Y, Sankawa U. Purification and characterization of emodinanthrone oxygenase from Aspergillus terreus. Phytochemistry 38: 299-305 (1995)

4. Huang KX, Fujii I, Ebizuka Y, Sankawa U. Molecular cloning and heterologous expression of the gene encoding dihydrogeodin oxidase, a multicopper blue enzyme from Aspergillus terreus. J Biol Chem 270: 21495-21502 (1995)

5. Mosmann T. Rapid colorimetric assay for cellular growth and survival: application to proliferation and cytotoxicity assays. J Immunol Methods 65: 55-63 (1983)

6. Ma YM, Li Y, Liu JY, Song YC, Tan RX. Anti-Helicobacter pylori metabolites from Rhizoctonia sp. cy064, an endophytic fungus in Cynodon dactylon. Fitoterapia 75: 451-456 (2004)

7. Turner WB. The production of trypacidin and monomethylsulochrin by Aspergillus fumigatus. J Chem Soc Perkin 1 6658-6659 (1965)

8. Ogawa T, Ando K, Aotani Y, Shinoda K, Tanaka T, Tsukuda E, Yoshida M, Matsuda Y. RES-1214-1 and -2, novel nonpeptidic endothelin type A receptor antagonists produced by Pestalotiopsis sp. J Antibiot 48: 1401-1406 (1995) 